UNIVERSIDADE DE SÃO PAULO

FACULDADE DE FILOSOFIA, LETRAS E CIÊNCIAS HUMANAS

DEPARTAMENTO DE SOCIOLOGIA

PROGRAMA DE PÓS-GRADUAÇÃo EM SOCIOLOGIA

ISABELLE DE MELO ANCHIETA

\title{
IMAGENS DA MULHER NO OCIDENTE MODERNO
}

SÃO PAULO

2014 


\section{UNIVERSIDADE DE SÃO PAULO}

FACULDADE DE FILOSOFIA, LETRAS E CIÊNCIAS HUMANAS

DEPARTAMENTO DE SOCIOLOGIA

PROGRAMA DE PÓS-GRADUAÇÃO EM SOCIOLOGIA

ISABELLE DE MELO ANCHIETA

\section{IMAGENS DA MULHER NO OCIDENTE MODERNO}

Tese apresentada ao Programa de Pós-Graduação em Sociologia do Departamento de Sociologia da Faculdade de Filosofia, Letras e Ciências Humanas da Universidade de São Paulo (USP) para a obtenção do título de Doutora em Sociologia.

Orientadora: Prof ${ }^{\mathrm{a}}$-Dri ${ }^{\mathrm{a}}$. Maria Arminda do Nascimento Arruda

SÃO PAULO

2014 


\section{AGRADECIMENTOS}

Meu primeiro agradecimento dirige-se aos cientistas sociais, especialmente aos sociólogos e ao esforço de elucidação das relações humanas. Importância que só pude compreender, de fato, durante um longo período de isolamento e de estudos. Quando me dei conta da sabedoria de Rousseau de que a felicidade e o seu oposto residem na nossa relação com os outros. A perspectiva sociológica me colocou no mundo de outra maneira, e não poderei ser mais quem eu fui depois dessa descoberta tão sentida. Tomando as palavras de um roteiro da personagem Sabrina (Audrey Hepburn) em um dos filmes que analisei: “Aprendi a viver... a estar no mundo e ser do mundo... não só ficar de lado e assistir. E nunca, nunca mais vou fugir da vida" ". E estar no mundo é estar com os outros _ sob pena de perdermos nossa face com o isolamento.

Esta é também curiosamente uma tese sobre a mulher que tem como alvo do meu primeiro agradecimento pessoal um homem: Juan José Pino. O companheiro que me ofereceu o apoio e a presença necessária para a mudança de Belo Horizonte para São Paulo para realizar meu Doutoramento na USP. Não só nesse momento decisivo, mas ao longo do processo, meu marido foi fundamental. Ele me ofereceu o afeto vital para essa longa e solitária experiência. Viajamos juntos à procura das imagens da pesquisa. Ele dirigiu por horas de uma cidade a outra, ajudando-me na comunicação com os bibliotecários e responsáveis pelos museus. Na Suíça, inclusive, auxiliou-me na seleção dos mais de 1.000 panfletos noticiosos do séc. XV. Confesso que ele colocou por terra todas as minhas reticências sobre o casamento, demonstrando como essa ligação pode ser uma parceria alegre. Sei que parece uma mistura de afeto e trabalho, mas ele me ensinou que não se pode ter entusiasmo por um se o outro falta. Trabalhei intensamente nesses quatro anos, mas também amei muito o que fiz e o homem ao meu lado.

\footnotetext{
${ }^{1}$ HEPBURN; WILDER, 1954.
} 
Em seguida, gostaria de agradecer aos integrantes da banca, os responsáveis ${ }^{2}$ pela oportunidade do meu Doutoramento na USP. Em 2009, fiz minha primeira tentativa de ingresso com um projeto que reconheço ousado em suas pretensões, especialmente pela longa duração. Apesar de os professores se dividirem sobre a viabilidade da pesquisa, houve, ao fim, um voto de confiança. Sobretudo conduzido por uma integrante: a professora Maria Arminda do Nascimento Arruda. Ela defendeu abertamente meu projeto, confiando em meu trabalho. Desde aquele encontro, estabelecemos uma conexão. Tanto que fiz um pedido ao departamento para que minha orientação fosse reconduzida a ela _ o que foi aceito, para minha alegria e da pesquisa. Ela me concedeu a liberdade necessária para produzir um trabalho autoral, auxiliando nas leituras e na reflexão com o respeito e a sensibilidade necessária a um bom orientador de tese.

Mais do que isso, Arminda é um exemplo como mulher para mim. Especialmente por saber combinar sua imagem com sua densidade intelectual. Uma mulher atravessada pela poesia e pelo conhecimento. Pela beleza e pelo dom das palavras. Por São Paulo e Minas Gerais. Ela caberia na descrição parafraseada de Gilberto Freyre: "Embora aparentemente simples é complexa, sutil, (...) um rosto esculpido na resistente matéria mineral" ${ }^{3}$. Tornamo-nos, sobretudo, amigas durante o processo de produção da tese.

Há, além de Arminda, dois professores fundamentais em minha formação na USP: Lilia Katri Moritz Schwarcz e Sérgio Miceli. Conheci Lilia na disciplina "Lendo Imagens", no Departamento de Antropologia. Se julgava saber analisar imagens, creio que reformulei a perspectiva depois dessa experiência. Desde o início, Lilia dizia que para ler imagens era preciso ver muitas imagens. Ela própria nos concedeu essa oportunidade em suas aulas, além de oferecer fundamentais referências de leitura. Mas, sobretudo, nos ensinou o delicado equilíbrio entre as perspectivas externalistas (que privilegiam o contexto social e político) e internalistas (que atentam para a importância do debate entre imagens).

${ }^{2}$ ARRUDA, Maria Arminda Do Nascimento; SALLUM JR., Basílio; COMIN, Álvaro; MUSSE, Ricardo; GARCIA, Sylvia Garcia. Banca de seleção para ingresso no Programa de Doutorado do Departamento de Sociologia da USP.2009. Departamento de Sociologia - FFLCH - USP.

${ }^{3}$ ARRUDA, 1999, p. 62. 
Lilia é perspicaz e clara nas análises e pessoalmente é doce e firme _ quando deve ser. O privilégio desse contato marcou em grande medida minha maneira de "ler" imagens.

Miceli foi um grande desafio. Tivemos uma série de embates durante o curso de "Sociologia Contemporânea" em 2010. Ele me desafiou, assim como os colegas, em diversas oportunidades. Não sei exatamente se o fez de maneira pedagógica ou não intencional, mas independentemente das motivações Miceli nos ensina a paixão por defender nossas ideias, ou mesmo colocá-las em questão. Ele oferece sangue aos pensamentos e sabe, como ninguém, dar vida e ação à academia. Eu o admiro em seu estilo polêmico e inteligente. O que tornou um elogio que recebi dele em público ainda mais sentido. Ao ser apresentada ao grupo de pesquisa do Projeto Temático ${ }^{4}$ Miceli disse: "Eu a conheço, foi minha aluna. Ela é genial”. Disso não vou esquecer-me. Ofereceu-me a confiança de ter vivenciado um grande desafio acadêmico no privilégio de sua presença.

Para além da instituição, estabeleci uma amizade acadêmica que foi central para a tese: o sociólogo francês Gilles Lipovetsky. Conhecemo-nos em 2008, quando fui a Madri para palestrar a respeito de um artigo em que apresentava as ideias germinais da tese. Estabelecemos um intenso diálogo desde então e nos tornamos grandes amigos. Contei com o privilégio de sua generosa acolhida e orientação tanto acadêmica como pessoal em suas visitas ao Brasil e em nosso intenso contato eletrônico. Ele me indicou autores e livros que ainda não circulavam no país e me incentivou nos momentos em que me tornava débil durante a pesquisa. Gilles sempre destacou a importância da criatividade na pesquisa para a formação de um intelectual e a reconhecia em meu trabalho. Ensinou-me o equilíbrio de respeitar o legado do conhecimento, mas não me eximir de produzi-lo.

\footnotetext{
${ }^{4}$ Projeto Temático: "Formação do campo intelectual e da indústria cultural no Brasil contemporâneo", do Departamento de Sociologia e Antropologia da FFLCH, apoio FAPESP.
} 
Há também uma influência fundamental no meu Doutoramento: os colegas. Agradeço por ter tido a oportunidade de ter colegas brilhantes com quem também aprendi muito, tanto quanto com os professores. Para destacar alguns: Cicélia Pincer, Herbert Rodrigues e Elaine Lima. Queria agradecer também o auxílio e a presteza da querida Irany Emídio, Gustavo Barbosa Mascarenhas, Vicente Sedrangulo Filho e Ângela de Sousa.

Por fim, quero lembrar da importância afetiva da minha família e de minhas amigas nesse período longe de sua presença. Pessoas que me apoiaram e me mantiveram amada mesmo de longe. Minha mãe, Adrienne Rabelo, a mulher que me ensinou o gosto por imagens e pela arte desde de muito cedo _ ela própria a mais bela imagem da mulher que já vi. Meu pai, Orlando, que tinha como seu o sonho do Doutoramento. A meus irmãos, Guilherme e João Felipe, e a minha querida irmã, Juliana. Além de contar sempre com a afetuosa acolhida de minha avó em seu jardim com príncipes negros no sul de Minas. E, claro, as minhas grandes e fiéis amigas Danielle Langsdorff, Alessandra Iacomini e Nívia Lemos.

Acho importante destacar também a presteza e a gentileza dos funcionários das instituições fora do país onde a pesquisa foi realizada. Dos museus e bibliotecas visitadas, especialmente de Munique e Zurique.

No mais, agradeço a todas as mulheres e homens pela oportunidade de ver e pensar sobre as suas imagens sem-fim... 
Dedico a tese à curiosidade humana, ao desejo de ver e pensar as mil faces das imagens sociais _ das quais apresento algumas_ na expectativa de ser esse trabalho uma prova do meu apreço por tudo o que foi e é tecido nas redes das nossas relações. 


\section{RESUMO}

A tese remonta uma gênese da imagem da mulher no Ocidente Moderno. Um processo em que se observa a transição de estereotipias, ora estigmatizadoras, ora idealizadas da mulher, que dão lugar ao longo do século XIX e XX às mulheres "encarnadas" _ com rostos individualizados e personalidades que gradualmente se apropriam de sua autoimagem. A mulher passa "de uma personagem a uma pessoa", Mas me pergunto: até que ponto presenciamos a ruptura com os estereótipos ou apenas presenciamos a criação de um novo tipo de estereotipia? Para responder a essa e a outras preguntas foi importante seriá-las. Aproximá-las. Contrapô-las. Pois, se, de fato, as imagens de que trato são amplamente conhecidas, falta pensá-las em conjunto, na longa série que as relaciona e tensiona dentro do processo social em que são formadas e que elas em grande medida conformam. Esse “corpo a corpo" entre as imagens traz surpreendentes elucidações sociológicas, na medida em que a remontagem envolve não só uma relação entre as imagens, mas coloca entremeio outros fatores: os atores, os grupos sociais, suas disputas por reconhecimento, os processos históricos, as tecnologias de comunicação, as estruturas de sentimentos. É nesse sentido que me proponho a fazer uma Sociogênese da Imagem. Uma visão não evolutiva, mas sim processual, em que ocorrem mútuas contaminações, continuidades, assimilações, hibridações e, por que não, rupturas entre essas imagens e linguagens. Um trabalho especialmente atento a elucidar de que forma a crescente importância da imagem humana _ gradativamente individualizada _ testemunha e instaura novas formas de organização e integração social.

Palavras-chave: Sociologia, Imagens, Mulher, Individumanização, Ocidente Moderno.

\footnotetext{
${ }^{5}$ MAUSS, 2003, p. 397.
} 


\begin{abstract}
The thesis goes back to the genesis of the image of the woman in the Modern Western era. A process in which we observe the transition of stereotypies, sometimes stigmatizing, sometimes idealized, of the woman giving place throughout the nineteenth and twentieth century to the "incarnated" woman _ with individualized faces and personalities that gradually appropriated from herself image. The woman passes "from a character to a person". Therefore, I wonder at what extent we witnessed the breakdown with stereotypes or just observed the creation of a new kind of stereotyping. To answer this and others questions it was important to seriate them. Bring them together. Align them. So, if the images that I present here are widely known, it is necessary to think them together, over the long series that relates and tensions them within the social process in which they are formed and in which they in large part conform it. This contend with images brings unexpected sociological elucidations, to the extent that the reassembly involves not only a relationship among images, but puts inset other factors: actors, social groups, their recognition disputes, historical processes, communication technologies and structures of feelings. That is the reason why I propose a Sociogenesis of the Image. A not evolutionary vision, but rather then a procedural one, where there are mutual contamination, continuity, assimilation, hybridization and, why not, a rupture between those images and languages. A study especially attentive to illustrate how the growing importance of human image _ gradually individualized _ witnesses and introduces new forms of social organization and integration.
\end{abstract}

Keywords: Sociology. Images. Woman. "Individualhumanization”. Modern Western. 


\section{LISTA DE ILUSTRAÇÕES}

\section{INTRODUÇÃO}

S/nome, Berthold Furtmeyer, 1481

01

\section{CAPÍTULO I- BRUXAS: ÍNDIAS}

S/nome, Theodore De Bry, 1592

Duas obras da trilogia "Peregrinações: da Alma, de Jesus e da Vida Humana". Guillaume de Deguieville, 1355

"Peregrinações: da Alma, de Jesus e da Vida Humana". Guillaume de Deguieville, 1426

Duas ilustrações de a História ilustrada do Vestuário. São Paulo: Publifolha, 2013

Ilustrações do livro "As Flores da Virtude", de Hans Vintler's, 1486

Ilustrações do livro “De Lamiis”, de Ulrich Molitor's, 1489, 1498, 1500, 1508

Ilustração (à dir.) do livro Le Champion des Dames Martin Le Franc, 1451

Ilustração (à esq.) do livro “As Flores da Virtude”, de Hans Vintler's, 1486

Ilustração do livro "Dois diálogos sobre o poder das bruxas", de Thomas Erastus, 1579

Esculturas de Epona e Diana, s/autoria, s/data

Michael Wolgemut, 1493; Albrecht Dürer, 1500; Hans Baldung Grien, 1510

Autorretratos de Autorretratos Albrecht Durer, 1495; 1500 (com 29 anos); em 1498 (com 27 anos), Museu do Prado, Madrid; e em 1493 (com 22 anos)

Ilustração de Michael Wolgemut (à esq.) e Albrecht Dürer (à dir.), c. 1516

Casal Sentado, 1495

Retrato da própria esposa, Albrecht Dürer, 1521

Ilustração de Albrecht Dürer (acima) e de Hans Baldung Grien (embaixo), 1510

S/nome, de Albrecht Dürer (esq.), 1497, e Hans Baldung Grien (dir.),

Duas imagens de "Aristóteles dirigido por Phyllis", de Hans Baldung Grien, 1513

Casal sentado, 1513 (esq.), duas imagens de "Aristóteles dirigido por Phyllis", de Hans Baldung Grien, 1513

"Melancolia", de Albrecht Dürer, 1514

Série "Melancolia", de Lucas Cranach, 1528-1532

Panfletos da coleção Johann Jacob Wick, 1522-1588

Panfletos, 1572

Panfleto, 1581

Folha volante, 1568

Panfleto, 1574

Panfletos da coleção Johann Jacob Wick, 1533 (esq.) e 1555 (dir.) 


\begin{tabular}{|c|c|}
\hline Carta original de Cristóvão Colombo, 1493 & 91 \\
\hline Ilustração do livreto "Insulis Inventis", 1493 & 92 \\
\hline Gravura de Albrecht Dürer, 1504 & 95 \\
\hline Ilustrações de "Crônica do Mundo", de Michael Wolgemut; Wilhelm Pleydenwurff; 1493 & $97-100$ \\
\hline Imagem do Novo Mundo, de Johann Froschauer, 1505 & 104 \\
\hline Imagem do Novo Mundo (detalhe), de Johann Froschauer, 1505 & 105 \\
\hline Folha volante, de Jan van Doesborch, 1509 & 106 \\
\hline "Lúcifer” (esq.), séc. XIV; “Juízo Final” (centro), de Fra Angélico, 1430; “A boca do Inferno” (dir.), de Fra Angélico, 1440 & 108 \\
\hline Ilustrações de narrativa de Américo Vespúcio, impressora de Grüninger, 1509 & 110 \\
\hline Ilustrações de narrativa de Américo Vespúcio, impressora de Grüninger, 1509 & $111-2$ \\
\hline Ilustrações de "Livro Segundo: A Terra e seus Habitantes", de Hans Staden, 1550-1555 & 116 \\
\hline Ilustrações do “Livro Primeiro: As Viagens", de Hans Staden, 1548-1549 & 121 \\
\hline Ilustrações de "Livro Segundo: A Terra e seus Habitantes", de Hans Staden, 1550-1555 & 122 \\
\hline Albrecht Durer, 1578 & 124 \\
\hline Antoine Chuppin, 1580 & $125-6$ \\
\hline Ilustrações de "Pequenas e Grandes Viagens", de Theodore De Bry e Hans Staden, 1592 & $129-30,133$ \\
\hline “Aristóteles dirigido por Phyllis", de Hans Baldung Grien, 1513 & 136 \\
\hline Ilustração do "Livro Primeiro: As Viagens", de Hans Staden, 1548-1549 & 137 \\
\hline Ilustrações de "Pequenas e Grandes Viagens", de Theodore De Bry, 1592 & 138 \\
\hline Panfleto coleção Johann Jacob Wick & 139 \\
\hline Ilustrações (esq. e centro) de "História dos Povos Nórdicos", do gravurista CG e Los Caprichos (dir.), de Francisco de Goya, 1815-24 & 140 \\
\hline Imagens de Staden, Jean Cousin e De Bry, 1557 & $141-2$ \\
\hline Ilustração, 1515 & 143 \\
\hline Ilustração de Jean Cousin, 1515 & $144,146-7$ \\
\hline Ilustração de "Pequenas e Grandes Viagens", de Theodore De Bry, 1592 & 148 \\
\hline Ilustração de "Pequenas e Grandes Viagens", de Theodore De Bry, 1592 & 150 \\
\hline Detalhes de "Juízo Final”, Fra Angélico, 1432-35 & 151 \\
\hline Ilustrações de Jean Cousin, 1515 & $152-4$ \\
\hline Ilustração de "Pequenas e Grandes Viagens", de Theodore De Bry, 1592 & 154 \\
\hline Ilustração (esq.) do "Livro Primeiro: As Viagens", de Hans Staden, 1548-1549 & $152-3$ \\
\hline Ilustração (dir.) de "Pequenas e Grandes Viagens", de Theodore De Bry, 1592 & 155 \\
\hline Ilustração do "Livro Primeiro: As Viagens", de Hans Staden, 1548-1549 & 162 \\
\hline "A Calúnia de Apelles", de Sandro Botticelli, 1495 & 166 \\
\hline Avareza, de Albrecht Dürer, 1507 & 167 \\
\hline "Três velhas batendo no Diabo", de Jacob Bink e Daniel Hopfer, 1500 & 168 \\
\hline "A bruxa atacando o Diabo", de Jacob Bink, 1528 & 169 \\
\hline
\end{tabular}




\begin{tabular}{|c|c|}
\hline “Anunciação de Maria”, de Mathias Gothardt Nithardt, “O Inferno" (dir.), s/autoria, 1505-1530 & 170 \\
\hline "Crônica do Mundo", de Michel Wolgemut, 1493; "Plato con ciruelas y guindas", de Juan Van Der Hamen, 1631; "Vanitas"”, de Jacques Linard, 1640 & 172 \\
\hline “Jovem mulher e a morte”, 1517; "Mulher e a Morte”, 1518/20; “Alegoria da Morte e da Beleza”, de Hans Baldung Grien, 1509 & 173 \\
\hline "Vanitas" (mais detalhes), de Hans Baldung Grien, 1509, Museu do Prado, Madrid & 174 \\
\hline S/nome, Theodore De Bry (1592) & 175 \\
\hline S/nome, de Hans Baldung Grien, 1510-1523 & 176 \\
\hline "Práticas Mágicas como crimes das Bruxas Diabólicas", de Hans Schäufelein, 1511 & 178 \\
\hline Imagem do ateliê de Grien, 1517 & 180 \\
\hline Ilustração (esq.) da obra de Johann Weyer, 1575, e da obra de Paulus Frisius (dir.), 1583 & 180 \\
\hline Ilustrações da obra de Abraham Saur, 1582 & 181 \\
\hline Ilustração da obra de Paulus Frisius, de 1583 & 182 \\
\hline "Cerco de Sancerre", panfleto da coleção Johann Jacob Wick, 1522-1588 & 184 \\
\hline Etienne Delaunne, 1575; s/nome, Compendiun das Bruxas, 1626 & 185 \\
\hline Ilustração (esq.) na obra de Jean Léry, s/d & 185 \\
\hline Os feitos Diabólicos da Feitiçaria”, na obra de Peter Binsfeld, 1592 & 186 \\
\hline Detalhes da imagem de Crispin de Passe, p. 186 & $187-91$ \\
\hline
\end{tabular}

\section{CAPÍTULO II - MARIA}

Maria" de Giotto de Bondone, 1310, Museu Uffizi, Florença, Itália

"Catacumba de Petrus" (1 $\left.1^{\mathrm{a}}\right)$ e "Marcellianus em Roma no séc. III" $\left(2^{\mathrm{a}}\right)$; detalhe $\left(3^{\mathrm{a}}\right)$ da Basílica Santa Sofia, Istambul (Constantinopla), Turquia (4 $)$

Basílica Católica de Santa Sofia (ou Sabedoria), 532 d.C.

Sacerdote faz oferenda à Deusa Cibele, 1 d.C.

Reproduções da Deusa Cibele, séc. XIII e XIV

"Maria", de Cimabue (1272-1302) de Toscana; de Duccio di Buoninsegna de Siena (1255-1319); e de Giotto de Bondone, Museu Uffizi, Florença, Itália

"Maria", de Cenni de Pepi (conhecido por Cimabue), 1240, Museu Uffizi, Florença, Itália

Detalhe da imagem de "Maria", de Cenni de Pepi/Cimabue), 1240

"Maria", de Duccio, 1311

Detalhe do Juízo Final, de Giotto, 1303-1304, Capela Arena Pádua, Itália

"Maria amamentando o menino Jesus", ilustrações no livro de Millard Meiss (1988)

"Virgem amamentando adultos", séc. XIII ( $1^{\mathrm{a}}$ e $\left.2^{\mathrm{a}}\right)$ e séc. XV $\left(3^{\mathrm{a}}\right)$, esta de Alonso Cano

"Virgem amamentando as almas do Purgatório", de Nicola Filotesio (1480-1547)

"Agnés/Maria" (em cima) e no detalhe (embaixo), de Jean Fouquet, 1450

Escultura de "Agnés", de Jacques Morel/Michel Colombe

"Maria guarda Jesus na cruz", de Giotto, séc. XIII (esq.) e séc. XIV (dir.) 


\begin{tabular}{|c|c|}
\hline "Vesperbielder", s/autoria, séc. XIV (1 $1^{\mathrm{a}}, 2^{\mathrm{a}}$ e $\left.3^{\mathrm{a}}\right)$; Maria de Miguel Ângelo $\left(4^{\mathrm{a}}\right)$ e no detalhe $\left(5^{\mathrm{a}}\right)$ & 220 \\
\hline "Natividade", de Giotto, 1223 & 223 \\
\hline Escultura da Natividade, s/autoria, séc. IV & 224 \\
\hline Mosaico Bizantino (1 $\left.1^{\mathrm{a}}\right)$, s/autoria, s/data; "Natividade" (2a), Giotto, 1305; Imagem do "Livro das Horas" ( $\left.3^{\mathrm{a}}\right)$, de Jean Fouquet, 1460 & 225 \\
\hline "Natividade", de Fra Angélico, 1438-1443, contendo São Marcos, Florença, Itália & 226 \\
\hline "Maria", de Piero de La Francesca, de 1470 & 227 \\
\hline Série da "Virgem", de Cimabue, de Théofanes, 1546, e de Frederico Barocci, 1597 & 228 \\
\hline "Vladmir", séc. XII; “Virgem” polonesa, séc. XIV; "Virgem” de Czestochowa & 229 \\
\hline "Caridade do Cobre" de Cuba, 1608, Nossa Senhora Aparecida do Brasil, 1717 & 230 \\
\hline "Nossa Senhora Aparecida", s/autoria, s/data & 232 \\
\hline Basílica de Nossa Senhora Aparecida em São Paulo, cidade de Aaparecida (SP/Brasil), 1980 & 233 \\
\hline Vida de Maria, de Jorge Inglês, s/data & 235 \\
\hline Ilustração de Livro das Horas, séc. XV & 237 \\
\hline "Nascimento de Santo Estevão", s/autoria, séc. XV & 238 \\
\hline “Cortejo nupcial de Segismundo I”, ilustração do livro “Crônica de Ulrico de Rinchental, 1429 & 239 \\
\hline Miniatura das Heures de Séguier, século XV. Chantilly, Museu Condé. In: CASAGRANDE, 1990, p. 120 & 242 \\
\hline Figuras de Aretino, de Giulio Romano/Conde de Waldeck/Agostino Carraci, s/data & 247 \\
\hline Sala de Amore e Pisiche (em cima), Palazzo Te, de Giulio Romano, s/data & 248 \\
\hline Júpiter e Olímpia (embaixo), de Giulio Romano, c. 1500 & 248 \\
\hline Retrato de Pietro Aretino, de Ticiano, 1545, Museu Palazzo Pitti, Florença & 249 \\
\hline "Figuras de Aretino", ilustram o livro "Sonetos Luxuriosos", 1527 & 250,252 \\
\hline Desenhos inspirados nas Figuras de Aretino, de Agostino Carraci, séc. XVI & 253 \\
\hline "Veronica", de Jacopo Robusti Tintoretto, 1570 & 260 \\
\hline "Veronica", de Jacopo Robusti Tintoretto/Domenico/Paolo Veronese, 1575 & 266 \\
\hline
\end{tabular}

"Veronica", de Jacopo Robusti Tintoretto/Domenico/Paolo Veronese, 1575

\section{CAPÍTULO III}

"Maria Madalena", Artemísia Gentileschi, 1615-1622

"Maria Madalena na Crucificação", Cimabue, 1290, Basílica de São Francisco de Assis, Assis, Itália

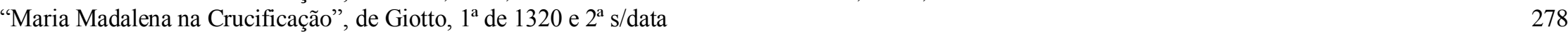

"São Domingos de Gusmão e Madalena", Fra Angelico, 1440-1442 280

"Madalena Pecadora", Fra Angelico, s/data

"Maria Madalena aos pés da Cruz", vários autores, s/data 283

283
284

"Crucificação", Matthias Grunewald/Mathias Gothardt Nithardt, 1515 


\begin{tabular}{|c|c|}
\hline "Crucificação", Matthias Grunewald/Mathias Gothardt Nithardt, 1515 & 286 \\
\hline "Crucificação", Matthias Grunewald/Mathias Gothardt Nithardt, 1515 & 287 \\
\hline "Êxtase de Santa Teresa", de Bernini, 1647, Gian Lourenço Bernini, Igreja Santa Teresa dela Vittoria, Roma & 293 \\
\hline "Êxtase de Santa Teresa", de Bernini, 1647 & 294 \\
\hline "Freiras atormentadas pelo demônio", detalhe das esculturas da Catedral de Chartres, França, séc. XVI & 295 \\
\hline "Madalena" (esq.), escultura, s/autoria/s/data, séc. XIV; pintura (dir.), Giovanni Lanfranco, 1604 & 300 \\
\hline “Assunção sonora de Madalena”, Gregor Erhart, 1515-1520 & 301 \\
\hline "Madalena", esculturas e pinturas de Giotto, 1320; de Lukas Moers, 1432; de Peras Matas, 1526 & 303 \\
\hline "Madalena no Deserto", de Antônio Allegri de Corregio, 1518-1519 & 305 \\
\hline "Madalena e a leitura do Evangelho", $1^{\mathrm{a}}$ e $2^{\mathrm{a}}$ de Pompeo Battoni, $1708 ; 3^{\mathrm{a}}$ de Raphael Menges, quadro Raphael Manges, 1752 & 306 \\
\hline "Madalena e o Livro Sagrado", de Ticiano Vecellio, 1560 & 307 \\
\hline "Madalena e o Livro Sagrado", de Ticiano Vecellio, 1560 & 308 \\
\hline "Vanitas de Madalena", de Guido Reni, 1577-1639 & 309 \\
\hline "Madalena" (esq.), de Guido Reni, s/data; (dir.), de Simon Vouet, 1623-1627 & 310 \\
\hline "Madalena" (esq.), de Orazio Gentileschi, 1621; (dir.), de Artemísia Gentileschi, 1621 & 313 \\
\hline "Madalena", de Artemísia Gentileschi, 1615 a 1622 & 313 \\
\hline "Madalena", de Artemísia Gentileschi, (esq.),1615-1616; (dir.), 1617 & 314 \\
\hline "Madalena", de Artemísia Gentileschi, 1621 & 315 \\
\hline "Madalena", de Miguelangelo Mersi Caravaggio, 1597 & 317 \\
\hline "Repouso durante a fuga no Egito", de Miguelangelo Mersi Caravaggio, 1595 & 319 \\
\hline "Madalena", de Jules Josef Lefévre, 1876 & 322 \\
\hline "Olympia" (esq.), 1863; "Jesus insultado pelos soldados" (dir.), 1864, de Édouard Manet, & 324 \\
\hline "Vênus de Urbino" (esq.), de Ticiano Vecellio, 1538; (dir.) de Manet, 1857 & 326 \\
\hline "Olympia" (acima), de Manet; "Vênus de Urbino" (embaixo), de Ticiano Vecellio, 1538 & 327 \\
\hline "Vênus Liggie" (acima), de Ticiano, 1565; "Vênus de Urbino" (embaixo), de Ticiano Vecellio, 1538 & 328 \\
\hline "Família", de Mary Cassatt, 1870-1900 & 333 \\
\hline "Mary Cassatt no Louvre", de Edgar Degas, 1880 & 334 \\
\hline "A mulher na Janela", que integra coleção privada, e "Lendo Romance", atualmente no Instituto de Arte de Chicago, de Mary Cassatt, 1880 & 335 \\
\hline "Lydia lendo no divã", de Mary Cassatt, 1881 & 336 \\
\hline Retrato de Berth Morisot com buquê de violetas, de Manet, 1872, A varanda, 1869, ambas no Museu d'Orsay Paris & 337 \\
\hline "O Berço", 1872; "Mulher e criança na varanda", 1872; "Julie Manet sonhando acordada", 1894, todas de Berth Morisot, & 338 \\
\hline "Retrato de Madame Hubbard", Berth Morisot, 1874 & 339 \\
\hline “La Chanson du Chien”, de Edgar Degas, 1875-1877 & 341 \\
\hline "Thérésa", de Edgar Degas, 1875 & 342 \\
\hline “Absinto", de Edgar Degas, 1875-1876 & 343 \\
\hline Retrato da atriz Ellen André, autor e data desconhecidos & 344 \\
\hline
\end{tabular}




\section{CAPÍTULO IV}

Retrato Rita Hayworth, 1940, Foto: A.L. Scafer, para Columbia.

Fotogramas de "Pollyana", filme de 1919

Mary Pickford na capa da revista "Photoplay", 1915

Mary Pickford e Owen Moore na capa da revista "Photoplay", 1914

Fotogramas de "Poor Little Peppina", 1916

Fotograma de "The poor little rich girl", 1917

Mary Pickford, David Griffith, Douglas Fairbanks Charles Chaplin, 1919

Fotogramas de "Pollyana", filme de 1919

Fotogramas de "Pollyana" (acima), 1916; e "The poor little rich girl" (abaixo),

Fotogramas de "Lírio Partido" com Lilian Gish, de 1919

Fotogramas de "Nascimento de uma Nação" com Lilian Gish, de 1915

"O mercado de casamentos babilônico" (esq.), de Edwin Long, 1875; e fotograma de "Intolerância", 1916

Fotograma de Órfãs da Tempestade" com Lilian Gish, 1921

Fotograma de "Escravo de uma paixão" com Theda Bara, 1915

"Olympia” (esq.), de Édouard Manet; 1863; fotogramas de "Escravo de uma paixão", 1915

Fotogramas de "Escravo de uma paixão" com Theda Bara, 1915

Fotogramas de "Sangue e Areia" com Nita Naldi, de 1922; e de Rita Hayworth como Doña Sol, 1941

"Vanitas de São Jerônimo meditando", ano; e fotogramas de "Sangue e Areia", de 1922

Cartazes de época de filmes de Theda Bara, 1915-1924

Fotogramas de "Cleópatra" com Theda Bara, 1917

Fotogramas de "Sangue e Areia", 1922

Fotogramas de Sumurun com Pola Negri, 1920

Fotogramas de "Mulher do Mundo" com Pola Negri, 1925

Fotogramas de "Torrent" com Greta Garbo, 1926

Fotogramas de "Torrent" com Greta Garbo, 1926

Fotograma de "Torrent"com Greta Garbo, 1926

Fotogramas de "A Carne e o Diabo" com Greta Garbo, 1926

Fotogramas de "Mata Hari” com Greta Garbo, 1931

Fotogramas "Rainha Cristina", com Greta Garbo, 1933

Fotogramas de "O Anjo Azul" com Marlene Dietrich, 1930

Fotogramas de "O Anjo Azul", 1930; gravuras, s/autoria, 1588

Fotogramas de "Marrocos" com Marlene Dietrich 1930

Fotograma de "O Expresso de Shangai” com Marlene Dietrrich, 1932 


\begin{tabular}{|c|c|}
\hline Marlene Dietrich entretendo as tropas do Exército americano, 1942-1943 & 406 \\
\hline Fotos de divulgação de Clara Bow, Paramount, c. 1927 & 407 \\
\hline Fotogramas de "It" com Clara Bow, 1927 & $409-10-11-12$ \\
\hline Fotogramas de "Asas" com Clara Bow, 1927 & 414 \\
\hline Fotogramas de "The Wild Party" com Clara Bow, 1929 & 415 \\
\hline Fotogramas de "Coquette" com Mary Pickford, 1929 & 418 \\
\hline Fotograma de "Escravos do Desejo" com Bette Davis, 1934 & 420 \\
\hline Fotogramas de "Jezebel, a insubmissa" com Bette Davis, 1938 & 424 \\
\hline Fotogramas de "Vitória Amarga" com Bette Davis, 1939 & 426 \\
\hline Fotogramas de "Vaidosa" com Bette Davis, 1944 & $427-8-30-31$ \\
\hline Fotogramas de "A Estranha Passageira" com Bette Davis, 1942 & 432 \\
\hline Fotogramas de “A Possuída” com Joan Crawford, 1931 & $435-7$ \\
\hline Fotograma de "Um rosto de mulher", com Joan Crawford de 1941 & $440-2-3$ \\
\hline Fotogramas de “Almas em Suplício” com Joan Crawford, 1945 & 444 \\
\hline Fotogramas de "Serenata Tropical" com Carmen Miranda, 1940 & 448 \\
\hline Fotogramas de "Uma noite no Rio" e "Aconteceu em Havana" com Carmen Miranda, 1941 & 449 \\
\hline Fotogramas de "Entre a Loura e a Morena” com Carmen Miranda, 1943 & 450 \\
\hline $\begin{array}{l}\text { Fotogramas de "Uma Noite no Rio, 1941, e "Entre a Loura e a Morena", } 1943 \text { (em cima); "Aconteceu em Havana", 1940, e "Entre a Loura e a } \\
\text { Morena", } 1943 \text { (embaixo) }\end{array}$ & 451 \\
\hline Fotogramas de “Entre a Loura e a Morena" com Carmen Miranda, 1948 & 453 \\
\hline Fotograma de "Banana da Terra" (esq.), 1938, cartão-postal (dir.), s/autoria, 1930 & 456 \\
\hline Turbantes usados em “Uma Noite no Rio", 1941; "Copacabana”, 1947; e "Romance Carioca”, 1950 & 457 \\
\hline Fotos do acervo Museu Carmen Miranda, RJ & $458-9$ \\
\hline Carmen Miranda em capa de revista com paper dolls (esq.) e ao lado de Mickey Rooney, 1943 & 460 \\
\hline Fotogramas de "Aconteceu em Havana" e "Uma Noite no Rio" com Carmen Miranda, 1941 & 462 \\
\hline Fotogramas de “Aconteceu em Havana” com Carmen Miranda, 1941 & 463 \\
\hline Fotogramas de "Gilda" com Rita Hayworth, 1946 & $464-5-6-8$ \\
\hline Fotograma de "Amores de Pandora" com Ava Gardner, 1951 & $469-72$ \\
\hline Fotogramas de "Pandora" (em cima), 195, e "Sangue e Areia" (embaixo), 1941 & 474 \\
\hline Fotogramas de "Sunset Boulevard" com Glória Swanson, 1950 472-3 & $477-78$ \\
\hline Fotogramas de Minha Rainha” com Glória Swanson, 1929 & 480 \\
\hline Fotograma de "Sunset Boulevard" com Glória Swanson, 1950 & $482-85$ \\
\hline Fotogramas de "A Malvada" com Bette Davis, 1950 & $486-87$ \\
\hline Fotogramas de "A Vaidosa" dom Bette Davis, 1944 (esq.) e A Malvada" com Bette Davis, 1950 & 488 \\
\hline Fotogramas de "A Malvada" com Bette Davis, 1950 & 491 \\
\hline Fotograma de "A Malvada", escultura em “A Malvada”, 1950; quadro de Joshua Reynolds; Bette Davis posando para a Revista Pageant, 1957 & 492 \\
\hline
\end{tabular}


Fotogramas de "A Malvada" com Bette Davis, 1950

Fotogramas de "A Malvada" com Bette Davis, 1950

Fotograma de "Almas Desesperadas" com Marilyn Monroe, 1952

Fotogramas de "Niagara" e "Os homens preferem as loiras" com Marilyn Monroe (1º e $\left.{ }^{\circ}\right), 1953$; "Gilda" com Rita Hayworth (3), 1946

Marilyn Monroe em capa de revistas famosas, 1949-1953

Fotogramas de "Como agarrar um milionário" com Marilyn Monroe, 1953

Fotogramas de "O Pecado Mora ao Lado" com Marilyn Monroe, 1955

Pin-ups de Gil Elvgren, anos 1950

Rosto de Marilyn Monroe, de Andy Warhol, 1962

Fotogramas de "Quanto mais Quente Melhor" com Marilyn Monroe, 1959

Fotograma de "O príncipe encantado" com Elizabeth Taylor, 1948

Fotogramas de "Um Lugar ao Sol" com Elizabeth Taylor, 1951

Fotogramas de "No Caminho dos Elefantes" com Elizabeth Tylor, 1956

Fotogramas de "Assim caminha a Humanidade" com Elizabeth Taylor, 1956

Fotogramas de "Cleópatra" com Elizabeth Taylor, 1963

Fotograma "No Caminho dos Elefantes" 1956 (esq.) e "Cleópatra" com Elizabeth Taylor, 1963

Fotograma de "A princesa e o Plebeu" com Audrey Hepburn, 1953

Fotograma de "Sabrina" com Audrey Hepburn, 1954

518

$521-2$

Fotograma de "Cinderela em Paris" com Audrey Hepburn, 1957

Fotos de Richard Avedon, s/data

Fotograma de "Cinderela em Paris" com Audrey Hepburn, 1957

Fotograma de "Cinderela em Paris", 1957

Fotograma de "Bonequinha de Luxo" com Audrey Hepburn, 1961

Fotogramas de "Barbarella" com Jane Fonda, 1968

"Um domingo de verão no Grande Jatte", de George Seraut, 1886

\section{CONCLUSÃO}

"La Tentative de l'ímpossible", de René Magritte, 1928, atualmente na Galeria Isy Brachot, Bruxelas

"Reprodução Proibida", de René Magritte, 1937, atualmente no Museu Boijmans Van Beuningen, Roterdã, (Holanda)

Imagens da campanha do Instituto Marquês Valle Flôr, em parceria com a ONU 


\section{SUMÁRIO}

INTRODUÇÃO

1.1

1.2

1.2.1

1.2.2

1.3

\section{EST}

1.3.1

1.4

1.5

1.5.1

Marcador no definido.

1.5.2 A bruxa como estereótipo aglutinador das notícias sensacionais

1.5.3 A descoberta de "homens e mulheres que andam nus" é notícia

1.6 AS PRIMEIRAS IMAGENS DOS CANIBAIS BRASILEIROS

1.6.1

1.6.2

1.7

1.7.1

1.7.2

1.7.3

1.8

1.8.1

1.8.2

Nudez e canibalismo

EM SÍNTESE: A BRUXA.

As feiticeiras peregrinas de Guillaume de Deguieville

A proliferação das bruxas em Hans Vintler's

A CONTRIBUIÇÃO

A síntese das imagens por Molitor's

O VOO DA BRUXA

Nua e canibal.

A SEGUNDA GERAÇÃO DE VIAJANTES “ETNÓGRAFOS”: HANS STADEN, JEAN LÉRY E THEODORE DE BRY ¡ERROR! MARCADOR NO DEFINIDO.

A sociologia e a etnografia visual de Hans Staden

Duas viagens ao Brasil, o livro de Hans Staden.

A diabolização da índia: por Staden e De Bry

ÍNDIA - O PODER DE CONTROLAR E DESCONTROLAR OS HOMENS

Pocaré: Sabá.

O caldeirão cani

bruxas europeias do séc. XVI
¡Error! Marcador no definido. ¿Error! Marcador no definido. EError! Marcador no definido. ¡ERROR! MARCADOR NO DEFINIDO. ¡Error! Marcador no definido. propriado pelas imagens das . ¡Error! Marcador no definido. 
1.8.3 A cauinagem de Debry como motor das funções e relações de gênero ¡Error! Marcador no definido. 1.9 O CANIBALISMO DAS VELHAS GULOSAS X ANTROPOFAGIA DO GUERREIRO TUPINAMBÁ...................... ¡ERROR! MARCADOR NO DEFINIDO.

1.10 O CALDEIRÃO CANIBAL: ÍNDIAS E BRUXAS ¡ERROR! MARCADOR NO DEFINIDO.

\section{CAPÍTULO II}

2.1 INTRODUÇÃO

2.2

O CORPO IMACULADO DE MARIA

¡ERROR! MARCADOR NO DEFINIDO. MENOS VIRGEM, MAIS MARIA.. ¡ERROR! MARCADOR NO DEFINIDO.

MARIA NEGRA

PEDAGOGIAS DA MORAL E DO PRAZER

2.6 AS FIGURAS DE ARETINO ¿ERROR! MARCADOR NO DEFINIDO. ¿ERROR! MARCADOR NO DEFINIDO.

CAPÍTULO III 195 ¡ERROR! MARCADOR NO DEFINIDO.

DA IMAGEM DA MULHER

3.3 A MODERNIDADE DA PROSTITUTA INDIFERENTE ¡ERROR! MARCADOR NO DEFINIDO. A MARIA CARNAL: A ASCENSÃO DA IMAGEM DE MARIA MADALENA E SEU PAPEL NA INDIVIDUMANIZAÇÃO . ¡ERROR! MARCADOR NO DEFINIDO. FRUSTRAÇÃO ¡ERROR! MARCADOR NO DEFINIDO.

\section{CAPÍTULO IV STARS} Error! Marcador no definido. DESTRUIDORAS DE LARES ¡ERROR! MARCADOR NO DEFINIDO. AS ESTRANGEIRAS ¡ ¡Error! Marcador no definido.

\section{Clara Bow: a It, flapper girl} ¿ERROR! MARCADOR NO DEFINIDO.

Mimadas, ricas e de família: a complexificação das personagens ¿Error! Marcador no definido. 
4.4.4 A mixagem ruidosa das Américas: a política da boa vizinhança .

¡Error! Marcador no definido.

4.4.5 Carmen Miranda: a "personalidade colorida"

EError! Marcador no definido.

4.5

APARENCIAS QUE ENGANAM

¡ERROR! MARCADOR NO DEFINIDO.
¡ERROR! MARCADOR NO DEFINIDO.

4.6

STARS DECADENTES: O CINEMA REFLEXIVO

4.6.1

A star sexy e atrapalhada: Marylin Monroe.

Error! Marcador no definido.

4.6.2 Uma mulher distinguida e com uma causa: Elizabeth Taylor

¡Error! Marcador no definido.

4.6.3

Audrey Hepburn: elegância e dissimulação

¿Error! Marcador no definido.

4.6.4

Barbarella: a heroína do futuro

¿Error! Marcador no definido.

CONCLUSÃO

¡ERROR! MARCADOR NO DEFINIDO.

REFERÊNCIAS ¡ERROR! MARCADOR NO DEFINIDO.

RELAÇÃO DE PÁGINAS DEDICADAS ÀS STARS

\footnotetext{
Audrey Hepburn

Ava Gardner

Bette Davis

Carmen Miranda

Clara Bow

Claudette Coulbert

Elizabeth Taylor

Glória Swanson

Greta Garbo

Jane Fonda

Joan Crawford

Lilian Gish

Marilyn Monroe

Marlene Dietrich

Mary Pickford
}

$520-38$
$469-75$
$421-33 ; 486-95$
$447-65$
$407-16$
418
$507-19$
$476-85$
$385-98$
$539-48$
$434-445$
$360-70$
$496-506$
$399-406$
$350-59 ; 417-8$


Rita Hayworth

464-68

Theda Bara 
ISABELLE de Melo ANCHIETA

Orientação: MARIA ARMINDA DO NASCIMENTO ARRUDA

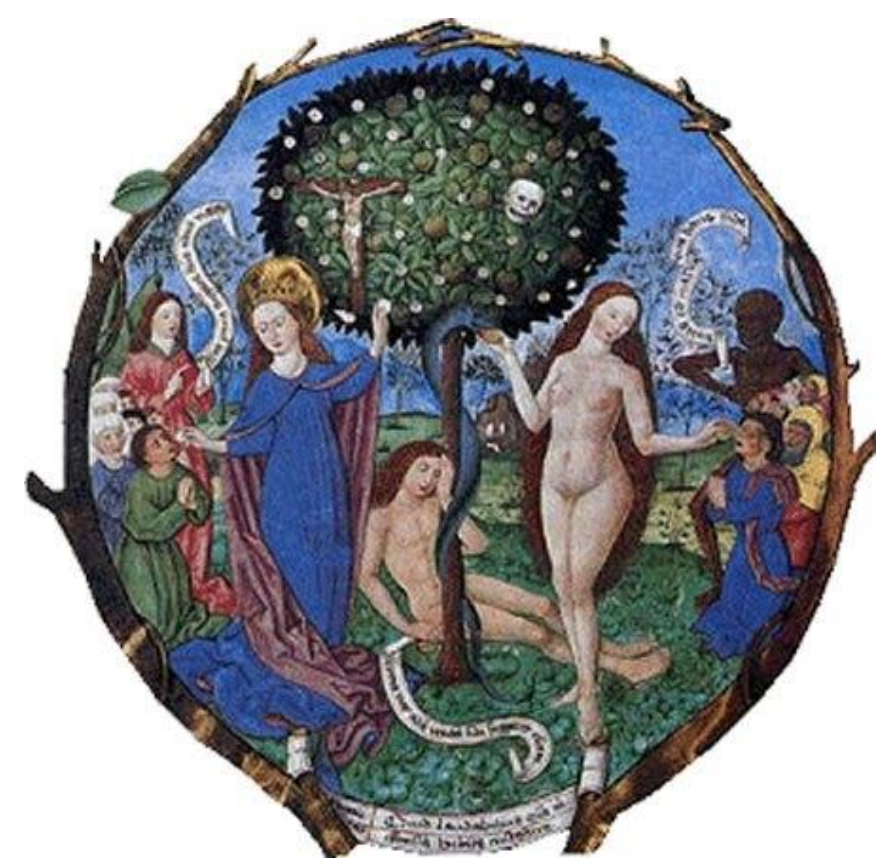

\section{IMAGENS da MULHER no Ocidente Moderno}

\section{INTRODUÇÃO}


${ }^{6}$ Por que o olhar alheio é tão importante na formação da nossa imagem? Para dar a medida da nossa existência? Por que disputamos, a todo momento, atenção, reconhecimento? Um olhar humanizante? Em que medida essa dependência constitutiva, precária e instável chega a ser mais significativa que a disputa econômica e a luta por sobrevivência? A gradativa busca pelo entendimento dessa dúvida foi também meu encontro com a Sociologia.

Ser visto, considerado, reconhecido é, dentre as pretensões sociais, a mais rigorosa, na medida em que instaura constantes disputas por existência social. Porque o aumento da consideração dos outros implica a potencialização do nosso sentimento de existir e o valor que nos atribuímos _ enquanto indivíduos e enquanto integrantes de grupos com os quais nos identificamos. Tal necessidade de "autoapresentação", , de "fazer-se ver" move-se, assim, na mesma direção da existência, das funções e das dependências recíprocas e não pode, por isso, ser reduzida a um ato narcísico _ no sentido de um amor-próprio (vaidade) ou um amor por si (como preservação). Trata-se sobretudo de uma interdependência sociológica e humana, que atrela nosso sentimento de satisfação, felicidade e valor ao outro. "Não há felicidade sem os outros", defendia Rousseau. Nossa existência, segundo ele, coincide com olhar alheio ${ }^{\mathrm{i}}$.

Seria essa a conclusão do filósofo no texto escrito em 1754 em razão de um concurso acadêmico da universidade de Dijon, na França, do qual saiu perdedor. Intitulado "Discurso sobre a origem e os fundamentos da desigualdade entre os homens", Rousseau enfatiza, neste texto,

\footnotetext{
${ }^{6}$ Em razão da diagramação, formatação e layout especial desta tese, as imagens podem não apresentar ordinariamente legenda nem fonte na página onde são exibidas, mas estão todas devidamente identificadas, com a informação da fonte, na Lista de Ilustrações. Quando a obra não tem nome/data, informa-se apenas ou autor; e vice-versa. Devido aos recorrentes acessos feitos aos mesmos websites de imagens e filmes durante os anos de elaboração da tese, informa-se o link, mas não a data da visita.

${ }^{7}$ Pois “nada e ninguém existe nesse mundo cujo próprio ser não pressuponha um espectador. (...) Nada do que é, à medida que aparece, existe no singular". Onde "Ser $e$ Aparecer coincidem" (ARENDT, 2010, p 35).

8 "Fazer-se ver: não no sentido de aparecer, mas nos variados sentidos de desenvolver qualidades sensitivas fundadas na percepção do olhar, na sensibilidade do ver, do transformar-se além do sujeito-em-visão, do mudar-se em ver, em coisa que se vê. Tornar-se olhar, fazer-se olho, fazer-se" (CANEVACCI, 2009, p. 26).
} 
a competição entre os homens por estima pública como o centro da explicação da origem da sociedade e de seus processos. Dá, assim, início à Sociologia "na acepção plena do termo"”.

Gradualmente comprovei em minhas pesquisas dedicadas à História social que a despeito da variabilidade dos processos algo permanecia: a disputa por visibilidade e reconhecimento. O contrário, por sua vez, foi (e ainda é) o grande temor: o menosprezo, a desconsideração, o silenciamento, a vexação, a vergonha social e a humilhação. Instaurando uma dinâmica social instável e tensa que o sociólogo Norbert Elias denominou de "Estabelecidos e Outsiders" ii . Em geral, trata-se da maneira como um grupo consegue afixar no outro um "valor humano inferior", que "costuma penetrar na autoimagem desse último e, com isso, enfraquecê-lo e desarmá-lo",iii.

Mas, se tal estereótipo fixou-se e foi relativamente aderido durante a Idade Média e no período colonial em relação a etnia, gênero, orientação sexual e cor, gradualmente observamos o descolamento da imagem hierarquizada do valor humano em prol da concepção da unidade e da igualdade _ valores com os quais a própria Modernidade Ocidental se confundiu. O que tem acelerado a disputa dos indivíduos e grupos por autoconfiança, autorrespeito e autoestima. Sentimentos que só podem ser gerados nas relações intersubjetivas mediadas pelas lutas de afeto, direitos e estima social, como bem sistematizou o sociólogo Axel Honneth ${ }^{\text {iv }}$.

Por essa razão, seria um equívoco acreditar que a disputa por visibilidade e reconhecimento tenha surgido com a chegada da Internet e das Redes Sociais. Ainda que nosso tempo nos reserve algo impactante: a ampliação e massificação dessa disputa individualizante por reconhecimento. Há uma profusão de imagens, rostos, vidas e pretensões que se ampliam na mesma grandeza do alcance das formas comunicativas. Todos tentam ser vistos, ouvidos e lidos nesse novo ambiente de integração social _ que demanda reciprocidades em um ciclo

\footnotetext{
9 "Rousseau não foi somente o precursor da sociologia na acepção plena do termo. Ele equacionou, ao mesmo tempo o problema do homem moderno, convertido em indivíduo político mas permanecendo, como seus congêneres, um ser social. Um problema que não nos abandonou” (DUMONT, 1985, p. 109).
} 
infindável de mútuas considerações. Um processo que tende simultaneamente ao individualismo e a interações ampliadas. Momento em que a face humana assume a imagem mais expressiva do direito de individualização em esferas de reconhecimento cada vez mais alargadas, desvelando a configuração social originária que liga Um a Todos. Pois o rosto é a imagem que nos singulariza e permite perceber que existe um eu e um nós em relação _ sendo o elemento visual fundante da sociabilidade. Seriam então as faces, gradativamente individualizadas, a nova imagem da socialização e integração humana pós-nacional no século XXI? Um novo humanismo que conecta um a todos?

Sobre essa imagem e configuração do nosso tempo escrevi um artigo que intitulei "A Sociedade de Rostos"10. Argumento que recebeu menção honrosa da Associação Internacional de Sociologia (ISA) com apoio da UNESCO, na Competição Mundial Jovens Sociólogos 2013/2014, sendo premiada junto a outros 7 jovens doutores. O trabalho antecipa minha hipótese teórica nesse percurso de oito anos de pesquisa. Qual seja? A de elucidar de que forma a crescente importância da imagem humana _ gradativamente individualizada _ testemunha e instaura novas formas de organização e integração social. Um processo que aponta para uma mudança na relação de poderes _ onde os indivíduos passam a questionar os estereótipos sociais, a soberania dos Estados-nação e mesmo a Cultura local, em defesa de algo que os transcende e os liga: a Humanidade. Ideia movediça que começa a ganhar materialidade através de organismos internacionais e pela demanda crescente por Direitos Humanos. Fatos que indicam uma nova tendência global nas relações humanas; uma nova forma de identificação e integração, que tem curiosamente como motriz a aceleração da individualização da imagem humana.

\footnotetext{
${ }^{10}$ RESUMO: Busco elucidar de que forma a crescente importância da imagem humana_gradativamente individualizada_instaura e testemunha novas formas de organização e integração social no sec. XXI. Momento em que o rosto emerge como imagem da humanidade. Parto para esta reflexão de seu avesso: a ausência de uma face. O drama de mulheres paquistanesas que tiveram seus rostos desfigurados por ácido por seus companheiros _ uma prática cultural que agrava-se desde o ano de 1999. Me interessa problematizar a circulação, o debate e a solidariedade que essa incomoda imagem despertou nas redes sociais brasileiras, motivando fóruns, reportagens e a promoção de organizações não governamentais em sua defesa nas diversas partes do mundo. Pretendo entender de que forma a violência contra a expressão mais visível da identidade social promove uma comoção para além das fronteiras étnicas, raciais e culturais, instaurando a ideia de humanidade (ANCHIETA, 2013, p. 1).
} 
A tese dedica-se a remontar a gênese moderna desse processo social de ampliação do reconhecimento da individualidade humana no Ocidente, concentrando-se na análise das imagens visuais, tidas aqui como armas simbólicas privilegiadas durante os imprevisíveis jogos por reconhecimento social. Dentre as imagens humanas elegi a imagem da mulher como estudo de caso. Tal escolha se dá porque foram elas, as mulheres, as principais responsáveis pela aceleração do processo individualizatório através da desarticulação da primeira e fundante ordem social: a família nuclear tradicional e seus fundamentos (casamento, maternidade e sexualidade). Os papéis sociais _ pai, filho, homem, mulher _ são profundamente abalados pelas "possibilidades eletivas emergentes" das mulheres ocidentais. Pois, apesar de o processo individualizatório não ser uma invenção dos últimos séculos ${ }^{11}$ nem ter sido gerado exclusivamente pela mobilização das mulheres, ele, no entanto, ganha propulsão através da mudança do estatuto e da imagem da mulher nas sociedades modernas e mesmo da necessidade de sua inserção como força produtiva. Elas passam, assim, a ter o direito de eleger o projeto biográfico como valor supremo, o que não significa que se tenham emancipado ${ }^{12}$ ou se autonomizado _ na medida em que a "individualização revela-se como a forma mais avançada de socialização dependente do mercado, do direito e da educação" "13. Fato que não se dá sem resistência de movimentos contrários de contramodernização; "desindividualização" ou mesmo no descompasso de estruturas institucionais historicamente constituídas (leis, escolas, costumes e etc.).

Nesse processo de individualização da imagem da mulher observaremos a transição de estereotipias ora estigmatizadoras, ora idealizadas da mulher _ Bruxas, Índias Canibais, Santas Marias, Madalenas _ que dão lugar ao longo do século XIX e XX às mulheres

\footnotetext{
11 "Foram os cristãos que fizeram da pessoa moral uma entidade metafísica. (...) Nossa própria noção de pessoa humana é ainda fundamentalmente uma noção cristã" (MAUSS, 2003, p. 392). "Eis a minha tese, em termos aproximados: algo do individualismo moderno está presente nos primeiros cristãos e no mundo que o cerca" (...) "Para outros a ideia de individuo nasce com a Renascença ou com a ascensão da burguesia” (DUMONT, 1985, p. 36)

12 "Muitos associam individualização com individuação (formação da personalidade, emancipação). Isto pode ser correto. Mas talvez também o seu contrário seja" (BECK, 2010, p. 191).

${ }^{13}$ BECK, 2010, p. 194.
} 
"encarnadas" _ com rostos individualizados como as Stars, no Cinema; as Pin-Ups e Top Models, na Publicidade e, agora, no XXI, aos retratos de milhares de mulheres possíveis nas Redes Sociais. A mulher passa "de uma personagem a uma pessoa" "14. Mas me pergunto: até que ponto presenciamos a ruptura com os estereótipos ou apenas presenciamos a criação de um novo tipo de estereotipia? Tiramos ou apenas trocamos a máscara? Para pensar sobre a questão gosto da reflexão do psiquiatra alemão Bruno Snell que nos diz: "Quando se dissipa uma ilusão, quando se rompe subitamente uma aparência, é sempre em proveito de uma nova aparência que retoma (...). A des-ilusão é a perda de uma evidencia porque é a aquisição de outra evidencia" ${ }^{15}$.

Para testar a validade dessas indagações e saber o real alcance dessa humanização, realizei uma Sociogênese ${ }^{\mathbf{1 6}}$ da Imagem ou, se preferirem, uma História Social da Imagem. Tento elucidar como se deu a gestação de formas estáveis amplamente reconhecíveis da mulher (ou de estereótipos) e sua mudança durante a modernidade, especialmente em direção ao retrato. Mais precisamente: Por que a despeito de tantas diferenças entre contextos e indivíduos as imagens da mulher tendem a uma feição comum no Ocidente? Por que essa feição sofre alterações de tempos a tempos? E como vincular essas mudanças na imagem da mulher com as disputas sociais por reconhecimento?

Para responder a essas preguntas foi importante seriá-las. Aproximá-las. Contrapô-las. Pois, se, de fato, as imagens de que trato são amplamente conhecidas, falta pensá-las em conjunto, na longa série que as relaciona e tensiona dentro do processo social em que são formadas e que elas em grande medida conformam. Esse "corpo a corpo" entre as imagens traz surpreendentes elucidações sociológicas, na

\footnotetext{
${ }^{14}$ MAUSS, 2003, p. 397.

${ }^{15}$ SNELL (apud ARENDT, 2010, p. 42).

${ }^{16}$ Nas palavras do sociólogo alemão Norbert Elias: “Algo vai decorrendo que, ao revelar-se se verifica não ter sido planejado nem requerido por nenhum indivíduo. No entanto, apareceu devido às intenções de muitos indivíduos. E isto, na verdade, representa todo o segredo da interpenetração social _ da sua obrigatoriedade e regularidade, da sua estrutura, da sua natureza processual e de seu desenvolvimento, isto é o segredo da sociogênese e das dinâmicas sociais" (ELIAS, 2011, p. 221).
} 
medida em que a remontagem envolve não só uma relação entre as imagens, mas coloca entremeio outros fatores: os atores, grupos sociais e seus interesses, os processos históricos, as tecnologias de comunicação e as estruturas de sentimentos. Por essa razão, tais encaixes, desencaixes e mesmo contaminações e fusões são mais delicados do que um mero jogo de montar imagens em um grande quebra-cabeças. Exige sensibilidade histórica, social e humana para ver e pensar as imagens como parte de um movediço arranjo social. Pois são as interações, os sentimentos sociais e as disputas por visibilidade o que de fato ligam, acionam e sustentam (ou não) as imagens e mesmo lhes conferem relativa autonomia.

Nessa direção, "nem a psicologia do indivíduo criador, nem a determinação de uma relação simples entre o artista e a sociedade permitem resolver as dificuldades" $"$. Pois as imagens são elementos que participam ativamente do jogo social, na medida em que não só "testemunham cenas e ambientes mas, da mesma forma, idealizam valores, costumes e concepções de mundo e sociabilidade"18. Mais do que nos levar à compreensão entre o homem-natureza, a imagem abre a possibilidade de desvelar a relação homem-sociedade, sendo antes o "testemunho da civilização". Por isso, a imagem não é nem expressiva, nem representativa, mas uma força ativa e social que deve ser estudada em si mesma. Visto que é "com o objeto figurativo e não com o real que se trava o diálogo e esse objeto é o produto não de um em-si, mas de uma experiência móvel e necessariamente coletiva" 19 .

A imagem não é um meio de informação ou de representação de uma realidade social que a preceda _ como um duplo, ou reflexo. É desenhada no arranjo societário. Integra-o. O que significa dizer, no âmbito desta tese, que as imagens da mulher participam, sofrem e modificam essa estrutura da qual são parte integrante _ testemunhando as mudanças dentro mesmo do processo social.

\footnotetext{
${ }^{17}$ FRANCASTEL, 1965, p. 92.

${ }^{18}$ SCHWARCZ, 2012, p. 11.

${ }^{19}$ FRANCASTEL, 1965, p. 117.
} 
É nesse sentido que me proponho, aqui, fazer uma Sociogênese da Imagem; que não significa uma remontagem contínua e teleológica. Mais do que uma linha, formam-se bordados sociais, entrelaçamentos, feitos de mútuas contaminações, continuidades, assimilações, hibridações e, por que não, rupturas entre essas imagens e linguagens. Uma visão não evolutiva, mas sim processual, o que significa nas palavras do antropólogo italiano Massimo Canevacci pensar os "processos de transformação, determinados por disjunções parciais, tensões conflituais, coexistências sincréticas e fraturas compositivas" ${ }^{20}$. Um método que se faz ainda mais necessário quando se fala em visualidades indisciplinares, “estendendo-se na vida cotidiana em quase todas as populações do mundo, compenetrando os corpos mentais e junto cruzando gêneros, estilos, linguagens, produtos, identidades bem além das distinções disciplinares ou das dicotomias funcionais"21.

Adotamos como pressuposto, nessa direção, que toda imagem é uma polimagem ${ }^{22}$. O que significa afirmar que uma imagem dialoga com outras em ordem e grandeza indefinida, na medida em que qualquer imagem, por mais originalidade que se arrogue, contém sempre a "citação" a outras imagens. Nas palavras do historiador de arte Ernest Gombrich, as imagens "falam entre si e concebem argumentos que lhe são próprios"23. Na medida em que a imagem está repleta de ecos e lembranças de outras imagens, "aos quais está vinculada no interior de uma esfera comum"24.

Uma imagem nunca é o ponto zero ${ }^{\mathrm{vi}}$. A ela precedem: outras intenções, outros atores, outros cenários. E, quanto mais se acumulam ao longo do processo social, mais complexas e multifacetadas se tornam as possibilidades de sua conformação. Nesse sentido, se é um equívoco

\footnotetext{
${ }^{20}$ CANEVACCI, 2009, p. 10-11.

${ }^{21}$ Ibid., p. 15.

${ }^{22}$ Este neologismo aqui proposto toma a etimologia com o prefixo poli que provém do grego polús, pollê, ú, numeroso, designando um número indefinido e elevado e também composição de uma variedade.

${ }^{23}$ SCHWARCZ, 2012, p. 12.

${ }^{24}$ BAKHTIN, 2000, p. 317.
} 
falar em imagens melhores ou piores da mulher com o passar do tempo, não o é, por outro lado, afirmar a maior e menor complexidade dos arranjos que se configuram (ou não) por meio desse estoque ${ }^{25}$ social de imagens.

Nesse sentido, voltar os olhos para a história da imagem da mulher não é limitar a mirada, mas abrir horizontes de compreensão. Nas belas palavras da socióloga Maria Arminda Arruda do Nascimento, "perceber a intromissão do passado em novas propostas não será um modo de captar direções futuras? Por isso, as análises centradas nas grandes durações não se constituem sempre em estudos menos profundos ou de menor significado histórico"26.

Quanto às imagens presentes no trabalho, gostaria de enfatizar que quase a totalidade delas foram vistas e analisadas pessoalmente. $O$ que demandou cinco viagens à Europa com duração média de 6 meses de pesquisa no exterior, em um total de 8 anos de pesquisa. Apesar de conhecer as reproduções dessas imagens através de livros e pela internet, foi de especial valor ter contato com o seu suporte original para entender seu sentido social. Visitei conventos, museus e bibliotecas na Itália, França, Espanha, Inglaterra, Suíça, Alemanha e Turquia (Istambul). Está a listagem completa no final da tese, junto à bibliografia.

O meu desejo de ver as imagens originais intrigou, inclusive, alguns bibliotecários dos locais onde se encontravam as obras raras. O que aconteceu, por exemplo, nas bibliotecas da Alemanha e da Suíça. Os responsáveis queriam desestimular minha viagem justificando ser o deslocamento desnecessário, já que as obras estavam digitalizadas em seus sites. Todavia, não abdiquei da oportunidade de conhecer o material _ insistência que os sensibilizou, facilitando, desde então, meu acesso. Deixaram-me, inclusive, fotografar a visita. Queria ver o tamanho da

\footnotetext{
${ }^{25}$ Para o canadense McLuhan "esta capacidade de armazenar é também um meio de transformar a experiência” (MCLUHAN, 1964, p. 79). "Na medida em que o acumulamos experiências nossas e dos outros - conhecidas pelos meios de comunicação_nos tornamos mais aptos a agir porque ampliamos as nossas experiências. Nesse sentido os meios como extensões do homem servem para fornecer uma consciência e uma visão transformadora” (MCLUHAN, 1964, p. 80).

${ }^{26}$ ARRUDA, 1999, p. 214.
} 
imagem, onde estavam posicionadas nos livros e panfletos, sua cor, textura _ fatores importantes para entender como a forma poderia condicionar a função ${ }^{27}$ social da imagem.

A relação da imagem com espaço era também importante para a minha imaginação histórica e sociológica ${ }^{28}$. Especialmente para que pudesse reconstituir o cenário das relações sociais e, assim, compreendê-las com profundidade. Tanto que fui tomada por vezes por uma “suspensão involuntária da incredulidade" me entregando aos efeitos emocionais causados por cada imagem. Esse sequestro emocional ao contrário de me afastar da análise crítica me auxiliou a compreender os efeitos sociais e sensíveis suscitados pelas imagens, passando de uma perspectiva a outra. Algumas análises que já haviam sido iniciadas tomando como referência a reprodução foram parcial ou mesmo completamente alteradas. O mesmo se passou com as pinturas nos museus e igrejas. A olho nu também me dei conta de detalhes que não pude perceber nas reproduções. Elementos diminutos e significativos que, por vezes, alteraram globalmente a interpretação sociológica do quadro.

Em se tratando do método de pesquisa, vale enfatizar que foi forjado simultaneamente com a noção proposta de polimagem. O que implica, na prática, a análise de séries de imagens. Um método que apreende a singularidade do fenômeno sem recair na ideia de arquétipos universais ou em particulares de baixa validade explicativa. Porque, se as unidades não representam isoladamente o universal cultural, ele emerge, no entanto, nas séries que incluem essas unidades, descortinando as “conexões transculturais"29. As séries retiram a imagem do seu artificial isolamento, reconstituindo movimentos e interações que são mais próximos e adequados para uma compreensão das práticas sociais. Porque, em definitivo, nem os objetos, nem a natureza, nem os homens existem isoladamente. Mesmo porque o sentido de existência de cada um é imprescindivelmente ancorado e mediado por diversas relações. Não sem razão o estudo das sequências históricas e visuais tornou-se o método

\footnotetext{
${ }^{27}$ No conselho do historiador de arte Gombrich, "nunca deve ser deixada de fora a função que se espera que uma imagem cumpra” (GOMBRICH, 2012, p. 7).

28 “A imaginação sociológica nos permite compreender a história e a biografia e as relações entre ambas, dentro de uma sociedade” (MILLS, 1969, p. 12).

${ }^{29}$ GINZBURG, 2007, p. 200; 204; 211.
} 
preferido de muitos pesquisadores ${ }^{\mathrm{vii}}$. Observaremos também os diálogos e hibridações entre imagens em diferentes suportes técnicos: a pintura, a escultura, a xilogravura e mais tarde a fotografia e o vídeo. Seria um fator limitador isolá-las, sob o risco de perder reveladoras relações entre imagens em meios distintos. Como bem nos alerta o antropólogo alemão Hans Belting em Antropologia da Imagem: "Na atualidade, numerosas teorias dos meios dão as imagens um papel secundário", torna-se um subproduto das reflexões e não a questão em si. Não é tomada em primeiro plano, como uma mediação que pode, inclusive, criar relações sociais: os gêneros, os sexos. Ou, "com miopia, se dedicam a um só meio técnico, como a fotografia ou o cinema. Uma teoria geral da imagem está ainda pendente ${ }^{\text {"30. }}$

\footnotetext{
${ }^{30}$ BELTING, 2007, p. 18.
} 



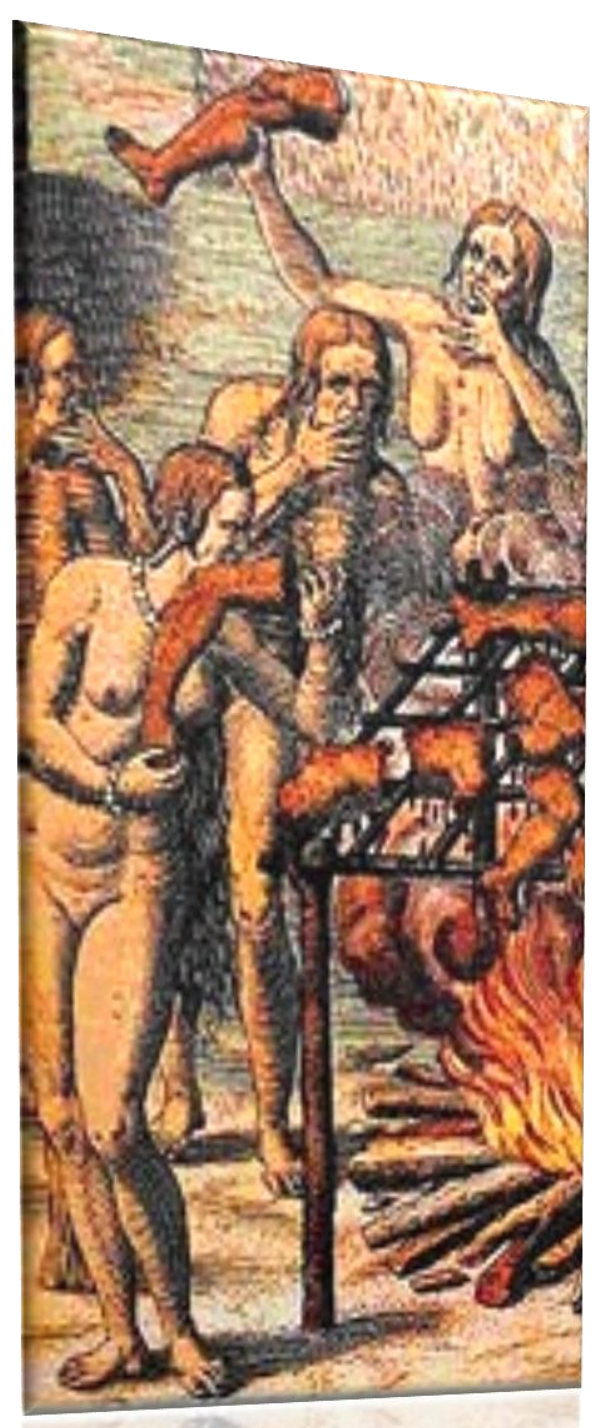

\section{A sobre-subumanidade das bruxas: índias antropófagas}

No capítulo remonto a sociogênese das imagens das bruxas e das índias tupinambás canibais e as suas mútuas contaminações durante os séculos XV e XVI. Ambas são imagens compostas por fortes tintas ficcionais que lhes acabam por retirar a humanidade. Tornam-se sobresubumanas produzindo um temor amalgamado por repulsa, atração, transgressão e pela tentativa do controle dos sentimentos. São, sobretudo, imagens detentoras de uma marginalidade atrativa. Na Europa as bruxas serão o estereótipo vigente para dar forma ao medo das inversões dos poderes entre homens e mulheres_associando uma suposta desordem privada a uma desordem social ampliada. Nas Américas as índias tupinambás brasileiras ecoam esse temor com um misto de erotismo, exotismo e animalidade. Imagens que se encontram, desvelando um dos modus operandi da imagem: a contaminação, no caso mútua. Conheceremos o diálogo entre essas imagens que tanto atormentaram e enfeitiçaram os homens na transição da Idade Média para a Moderna e sua transformação nesse encontro.

\section{CAPÍTULO I}




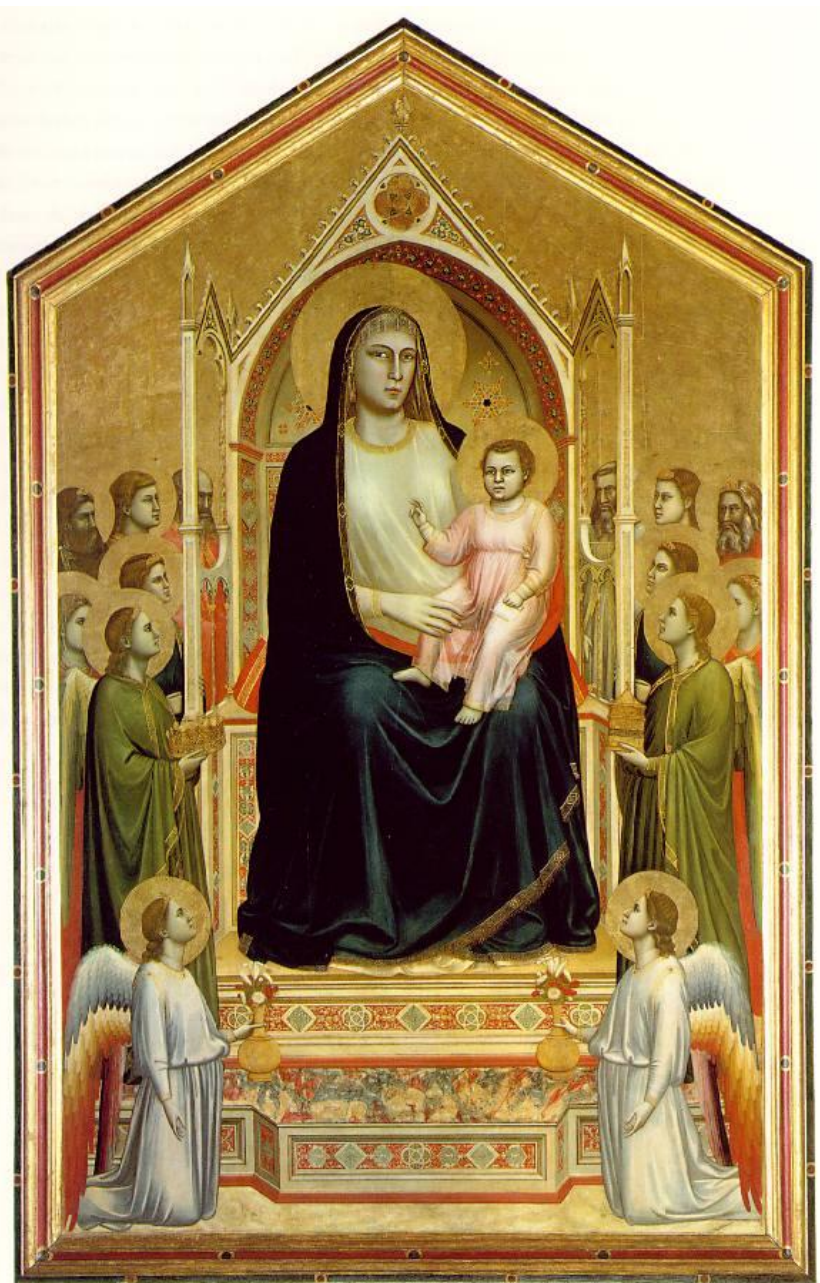

DA MARIA VIRGEM À CARNAL

Neste capítulo, concentro-me na remontagem de uma sociogênese da imagem de Maria. Conhecida por um nome e representada de mil maneiras: de Virgem a Negra. Impressionantemente flexível, mas coerente na proposta de representar o ideal de uma imaculada bondade, a Virgem é ao mesmo tempo única e mediadora de todos, incorporando e atuando nos mais diversos conflitos de ordem religiosa, moral e econômica. Atende aos anseios de legitimação e poder da Igreja, mas também é a imagem escolhida pelos mendicantes como bandeira da reforma interna da Igreja. Desce do trono e pisa descalça a terra nas imagens da Natividade. Nas Américas se torna Negra e funciona como uma mediação afetiva para dulcificar os ânimos, auxiliando a colonização e o contato entre o Novo e o Velho Mundo. É, em contrapartida, a grande a vila dos protestantes e de certa forma das mulheres casadas e das prostitutas. Mas, apesar de tantos embates, mudanças iconográficas e pathos morais, algo se processa: sua humanização _ ainda que incompleta. Seu limite estava demarcado na ausência de sua sexualidade. Apresento nesse sentido sua difícil aderência para mulheres que "perderam o selo virginal" (as casadas e as prostitutas). Uma pedagogia visual moral que concorria com as imagens pornográficas que circularam intensamente, como se verá. Disputas que não impedem que Maria seja a imagem mais bem-sucedida e popular criada pela religião ocidental. Ainda que não possa ser, como Deus foi para o homem, a imagem da mulher.

CAPÍTULO II 


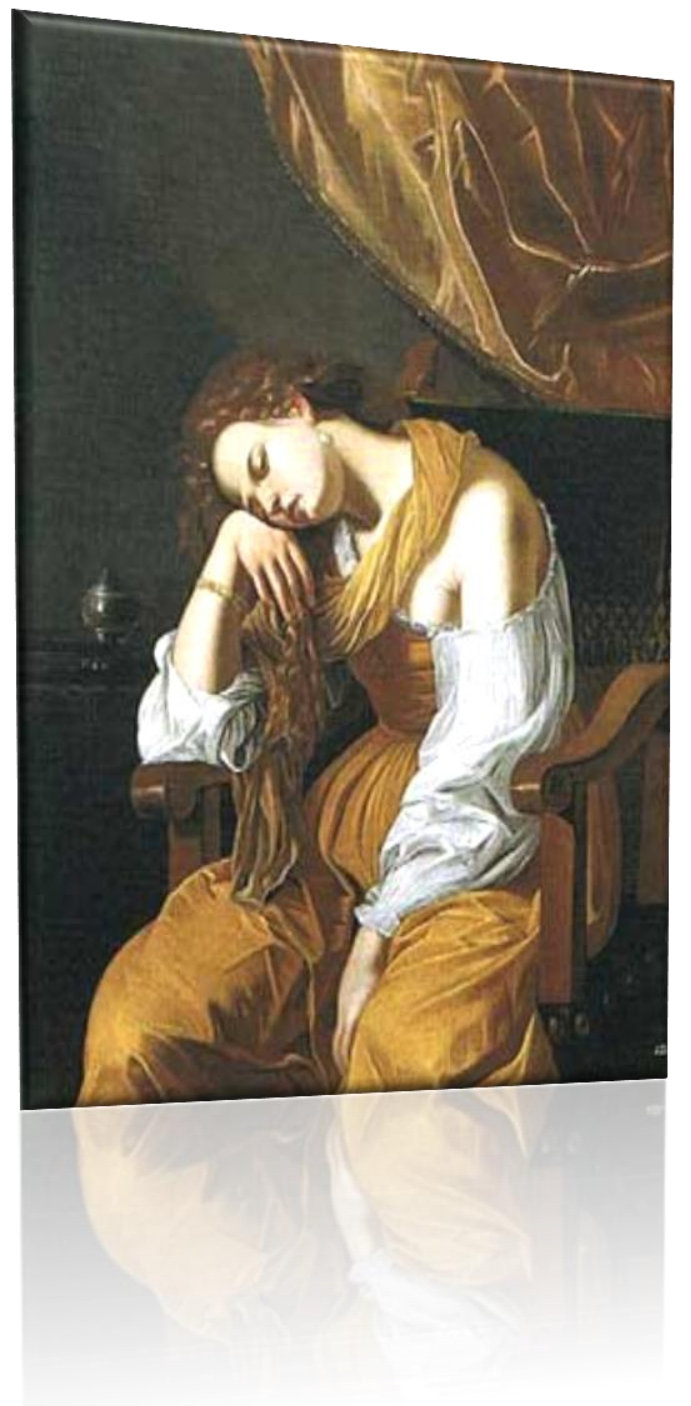

A modernidade da prostituta: de arrependida a indiferente

A mais humana das santas, Maria Madalena. Carnal, pecadora. Ela forja-se em uma direção improvável para a Virgem, inaugurando uma pedagogia da salvação às avessas: do pecado à santificação. O que implicava submeter-se a uma eterna expiação e penitência, negando o seu ser no mundo. Um autoabandono. Sinônimo do arrependimento, Madalena foi a imagem preferida pelos mendicantes. Chegando a ser, durante a Reforma e a Contrarreforma, a imagem que concorre com a da Virgem, ocupando o centro da Cruz _ mesmo que aos pés dela. Madalena é um sintoma de uma mudança de mentalidade em curso na direção da humanização $e$ desencantamento do mundo. Aos poucos, a própria imagem da prostituta secularizase colocando, de forma incômoda, seu corpo como tema. Sendo Olympia de Manet a sua mais despudorada ruptura moral. Uma prostituta sem sinais de arrependimento. Ainda que preserve no olhar uma profunda indiferença. Um sentimento que vibra com uma modulação menos edificante e moral e mais incerta e humana. Uma prostituta irônica, reflexiva, que representa sobretudo a frustração de uma promessa de liberdade e individualismo. Uma frustração não só para as prostitutas, como também para as mulheres honestas e românticas, que percebem no casamento por amor uma efêmera possibilidade de vivenciar a felicidade. Um capítulo que trata, nesse sentido, de distintas modernidades dentro da modernidade, seguindo os passos da imagem.

\section{CAPÍTULO III}




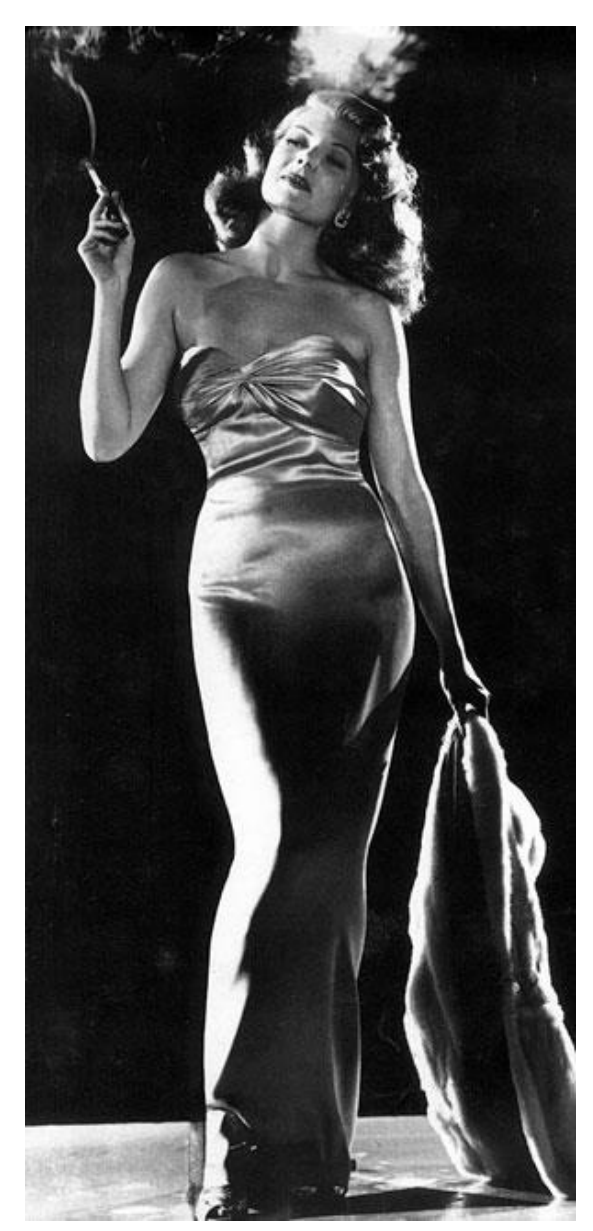

CAPÍTULO IV
STARS: estereótipos personalizados

As imagens em movimento das Stars de Hollywood criam uma forma inédita de estereótipo: personalizado, com um rosto, por assim dizer. Imagem que testemunha e, em grande medida, cria um novo sistema de relações sociais centrado no indivíduo e amalgamado por realidade e fantasia. Haverá o estereótipo de Mary Pickford, Theda Bara, Greta Garbo, Bette Davis, Marilyn Monroe e Audrey Hepburn _ para nomear algumas das 19 estrelas selecionadas para este capítulo. Cada qual conseguirá delinear sua personalidade for do comum e rostidade com a manutenção de certo comportamento definidor ao longo de sua filmografia. Fixam uma imagem-personalidade reconhecível e invertem a ordem de representação. É a personagem que se encaixa a elas e não elas à personagem. Um sucesso em grande medida definido pela capacidade de provar sua existência distintiva para além das telas, contribuindo para a perda dos limites entre o público e o privado. Uma contínua dissimulação que conduz à aderência visual da personagem. Uma imagem criada por muitas mãos que esculpem um rosto em close-up. Uma protagonista fora do comum _ composta pela mixagem de imagens do passado e do futuro. Da realidade e da fantasia. Representam anseios modernos, mas também criam comportamentos sociais inéditos. Oferecem "esquemas de conduta" "31 para as pessoas comuns. Passando dos padrões de embelezamento, vestuário ao maneirismo com o objetivo de obter um suposto sucesso social. São imitadas, misturadas, adoradas, mas também descartadas pelo público. Funcionam como uma instituição pedagógica movediça da modernidade. Analisaremos a sua conformação revelando uma história social das imagens do cinema. Como elas dialogam com as imagens que as precedem, mas como também criam uma história que lhes é própria.

\footnotetext{
${ }^{31}$ BLUMER, 1933.
} 


\section{NOTAS DE FIM}

i “Cada um começa a olhar os outros e a querer ser olhado por sua vez, e a estima pública tem um preço. Aquele que canta e dança melhor, o mais belo, o mais destro ou o mais eloquente, torna-se o mais considerado. E foi esse o primeiro passo para a desigualdade e o vício, ao mesmo tempo: dessas primeiras preferencias nasceram, de um lado, a vaidade e o desprezo e, de outro, a vergonha e a inveja, e a fermentação causada por esses novos fermentos produziu, enfim, compostos funestos à felicidade e à inocência. Logo que os homens começaram a se apreciar mutuamente, e que a ideia da consideração se formou em seu espírito, cada um pretendeu ter direito a ela, e não foi possível faltar com ela impunemente a ninguém. Daí surgiram os primeiros deveres de civilidade, mesmo entre os selvagens, e daí toda falta voluntária tornou-se um ultraje, porque, com o mal que resulta da injúria, o ofendido via nela também o desprezo à sua pessoa, muitas vezes mais insuportável que o próprio mal. Foi assim que, punindo cada qual o desprezo que lhe testemunhara de maneira proporcionada ao juízo que de si mesmo fazia, as vinganças se tornaram terríveis, e os homens sanguinários e cruéis" (ROUSSEAU, 1754, p. 25).

ii "Na atualidade é comum não se distinguir a estigmatização grupal e o preconceito individual e não relacioná-los entre si” (ELIAS, 2000: 23).

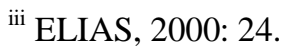

${ }^{\text {iv }}$ HONNETH, 2003.

v “Também nas sociedades modernas encontram-se dimensões desindividualizadoras. Sem contar a religião que permanece como possibilidade para amplas camadas sociais, há outras alternativas de desindividualização através da carreira, da participação em certas instituições e da própria família” (VELHO, 1997, p. 29).

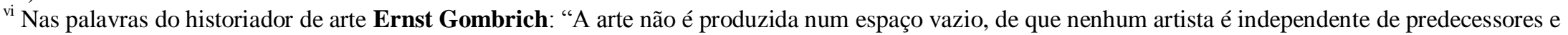
modelos, de que ele, tanto quanto o cientista ou o filósofo é parte de uma tradição específica e trabalha numa área estruturada de problemas” (GOMBRICH, 2007/1977, p. 25). No mesmo sentido Merleau Ponty afirma: as imagens "dependem daquelas que a precedem, e sua sucessão cria uma realidade nova, que não é a simples soma dos elementos empregados" (MERLEAU-PONTY, p. 111, 1983). A imagem "não se situa entre o visto e o visual, mas entre o visual e um outro visual". Ou ainda André Rouillé: "entre o real e a imagem sempre se interpõe uma série infinita de outras imagens, invisíveis, porém operantes" (ROUILLÉ, 2009, p. 158).

vii Como Aby Warburg, Francastel, Georges Duby, Michelle Perrot, Ernst Gombrich, Margaret Mead, Erving Panofsky, Baxandall, Starobinsky, para citar alguns. Nas palavras do historiados de arte, Aby Warburg as séries possibilitam pensar “as continuidades, rupturas e sobrevivências entre as imagens (...). Por exemplo, quando a Salomé dançante da Bíblia aparece como uma mênade grega ou como quando uma serva que carrega um cesto de frutas - assim como foi imitada de modo plenamente consciente por Ghirlandaio ocorre no estilo de uma Vitória de um arco do triunfo romano" (WARBURG, p. 126, 2009). Não sem propósito o historiador denomina a imagem de "órgão da memória social", dada a sua capacidade de armazenamento imaginário. Na introdução da obra História da Mulher, o historiador Georges Duby e a historiadora Michelle Perrot afirmam que "só uma análise serial permite compreender algo da sua organização sexuada" (DUBY \& PERROT, 1990). ${ }^{\text {vii }}$ Criticando a ideia de que as séries revelariam cópias e imitações, o historiador de arte Baxandall chama a atenção que o mais interessante é pensar os "jogos de posição, e cada vez que um artista sofre uma influência reescreve um pouco a história de sua arte" (BAXANDALL, p. 103, 2006). 